\title{
A STRATEgic APProACh to NetWork VALUE IN NETWORK INDUSTRIES*
}

\author{
Lucio Fuentelsaz \\ Departamento de Dirección y Organización de Empresas \\ Universidad de Zaragoza \\ Gran Vía, 2 - Zaragoza, Spain \\ lfuente@unizar.es
}

Elisabet Garrido

Departamento de Dirección y Organización de Empresas

Universidad de Zaragoza

Gran Vía, 2 - Zaragoza, Spain

egarrido@unizar.es

\author{
Juan Pablo Maicas \\ Departamento de Dirección y Organización de Empresas \\ Universidad de Zaragoza \\ Gran Vía, 2 - Zaragoza, Spain \\ jpmaicas@unizar.es
}

Forthcoming, Journal of Management

Final version: April 2012

\footnotetext{
*Acknowledgements: We acknowledge financial support from the Spanish Ministry of Economy and Competitiveness and FEDER (projects ECO2011-22947 and ECO2008-04129/ECON) and the Regional Government of Aragón and FEDER (project S09). Garrido is also grateful to the Spanish FPU Program (AP2008-02327). We thank Michael Leiblein and two anonymous referees for their valuable comments and suggestions, as well as the participants at the $1^{\text {st }}$ Seminar of the Generés Research Group. Any errors are the sole responsibility of the authors.
} 


\title{
A Strategic Approach to Network VAlue in Network Industries
}

\begin{abstract}
This paper extends previous research on network industries by analyzing the role that firm strategy plays in markets where network effects are important. We postulate that firms can benefit from the existence of network effects through their strategic choices. The main premise of the paper is that companies, by influencing expectations, coordination and compatibility, can leverage network effects and network value. We empirically test our hypotheses in the mobile telecommunications industry, a paradigmatic example of a network industry. This study not only seeks to understand the impact of firm strategy on network value, but also analyzes the impact of the latter on firm performance.
\end{abstract}

Key words: Network value, network effects, time in the market, internationalization, switching costs, firm performance 


\section{A Strategic Approach to Network VAlue in Network Industries}

\section{INTRODUCTION}

Network industries, defined as those in which network effects are important to understand how firms compete, represent a large and growing portion of today's economy. Software, mobile communications and video games are just a few examples of industries where network effects drive market competition (Shankar and Bayus, 2003; Tanriverdi and Lee, 2008). In recent years, management and economic literature have devoted increasing attention to these industries (Farrell and Klemperer, 2007; McIntyre and Subramaniam, 2009; Shankar and Bayus, 2003). This may be a reaction to evidence that network industries seem to challenge much of the thinking derived from previous models and findings (Shapiro and Varian, 1998; Suarez, 2005). However, although recent literature recognizes that the foundations of network effects have received an increasing amount of attention from researchers (Varian and Shapiro, 1998; Farrell and Klemperer, 2007), a deeper understanding of the role that firm strategy plays in leveraging network effects is needed (McIntyre and Subramaniam, 2009).

One of the main premises of businesses such as software and telecommunications is that the firm's installed customer base can be considered a key strategic asset to gain sustainable competitive advantages (Shankar and Bayus, 2003). This is because the existence of network effects implies that consumers' utility is directly affected by the number of consumers using the same product or technology (Shy, 2011) and, thus, customers' willingness to pay increases, with the subsequent potential impact on firm performance (Shapiro and Varian, 1998; Shankar and Bayus, 2003). 
There is a growing body of literature that attempts to measure network effects in a variety of industries. This stream of research is mainly focused on technological standards competition (Cowan, 1990; David, 1985; Garud and Kumaraswamy, 1993), technology adoption and diffusion (Gandal, Kende and Rob, 2000; Goolsbee and Klenow, 2002; Majumdar and Venkataraman, 1998; Park, 2004) or the analysis of hedonic price functions for products exhibiting network effects (Brynjolfsson and Kemerer, 1996; Hartman and Teece, 1990, Gandal 1994). However, only a few papers have analyzed how firms' strategic decisions may influence performance when network effects are important. These papers have paid attention to the impact of strategic dimensions such as entry timing and learning orientation (Schilling, 2002), product diversification (Tanriverdi and Lee, 2008) and pioneers' advantages (Eisenman, 2006). One commonality of these works is that they focus their attention on specific attributes of strategic choices, without establishing a general model about how strategy helps firms to gain a competitive advantage in network industries.

Our research attempts to explain how firm-initiated strategic actions can help firms to benefit from the existence of network effects. Following McIntyre and Subramaniam (2009), our paper aims to study the implications of strategy in network industries in greater depth. We build on both economic and strategic literatures under the premise that understanding the drivers of network effects will allow firms to adopt a more proactive position and intensify the network effects to their own benefit. We also extend previous research by suggesting that network value, defined as "the value stemming from other consumers already using the product" (McIntyre and Subramaniam, 2009:1496), is more accurate than network size for assessing a firm's competitive position in the presence of network effects. In contrast to most of the existing empirical literature (Brynjolfsson and Kemerer, 1996; Schilling, 2002), we propose an adjusted measure of network value, based on Metcalfe's law, that includes not only network size but also network intensity. 
L. Fuentelsaz, E. Garrido and J.P. Maicas (2012).

A strategic approach to network value in network industries (JOM, Forthcoming)

Previous literature has identified three elements that act as antecedents of network effects (Farrell and Klemperer, 2007; Katz and Shapiro, 1994; Shapiro and Varian, 1998), namely, users' expectations, users' coordination and compatibility among competing networks. We postulate that firms, by managing these elements through their strategic decisions, can leverage network effects and increase network value in the industries in which they operate. In particular, we study how several strategic initiatives based on the management of the installed base, such as entry timing, internationalization and switching costs, are related to users' expectations, users' coordination and compatibility among competing networks and, eventually, to network value.

Focusing on firm-initiated actions that shape the firm's competitive destiny in network industries, we bring a strategic dimension to the research in this field by offering a theoretical model that relates strategic actions and the drivers of network effects. This analysis focuses on the concept of network value, which has been previously analyzed from a theoretical perspective in the literature. The main contribution of this paper lies in the proposal and analysis of an improved measure of network value that integrates the size and intensity dimensions of network effects in an empirical analysis. Finally, this study not only seeks to expand on prior findings by including the effect of firm strategy on network value, but also analyzes the impact of network value on firm performance.

We empirically illustrate the hypotheses of our study with an application to the European mobile communications industry, which is a paradigmatic example of the existence of network effects (Srinivasan, Lilien and Rangaswamy, 2004). We use a longitudinal panel spanning the period 1998 to 2008 . The data refers to the network value and performance of 65 companies in 20 European markets. We find that entry timing is positively related to network value, while the level of switching costs is negative. On the contrary, the 
L. Fuentelsaz, E. Garrido and J.P. Maicas (2012).

A strategic approach to network value in network industries (JOM, Forthcoming)

international scope of the firm seems not to have any significant influence on network value.

Our results also reveal that network value is a critical determinant of firm profitability.

The rest of the paper is organized as follows. The next section develops the theoretical model, paying special attention to the relationship between network effects and network value and between the latter and its main antecedents: expectations, coordination and compatibility. This section also provides a theoretical explanation of the effect of three strategic initiatives, namely, entry timing, internationalization and switching costs management, on network value. We also analyze the relationship between network value and the performance of firms. The data from the European mobile communications industry and the variables used are presented in the third section, while the fourth describes the estimation procedure. Following that, we provide evidence on the impact of entry timing, internationalization and switching costs on network value and the influence of the latter on firm performance. We close the paper by discussing its main findings and its managerial and policy implications.

\section{THEORY AND HYPOTHESES}

\section{Installed Base, Network Effects, Network Value and Network Intensity}

Previous literature has highlighted the role of the installed base as a strategic asset in network industries (Brynjolfsson and Kemerer, 1996; Chacko and Mitchell, 1998; Shankar and Bayus, 2003). The installed base can be defined as "the cumulative number of users at any given time in the product's life" (McIntyre and Subramaniam, 2009:1495). This strategic consideration of the installed base in network industries is explained by the existence of network effects that are present when "the utility that a user derives from consumption of the good increases with the number of other agents consuming the good" (Katz and Shapiro, 
L. Fuentelsaz, E. Garrido and J.P. Maicas (2012).

A strategic approach to network value in network industries (JOM, Forthcoming)

1985: 424). Thus, user utility is dependent on the size of the installed base (Shapiro and Varian, 1998) and this results in interdependent demand (Rohlfs, 1974).

The importance of the installed base to gain competitive advantages is clear in markets whose network effects are direct or pure, ${ }^{1}$ such as the telephone, fax and e-mail industries. Stand-alone benefit is negligible because the product or service has to be integrated into a network to obtain value from it (DePalma and Leruth, 1996; Grajek, 2010). Given the existence of network effects, the main competitive advantage of the firm is based on creating a higher network value than its rivals, and not exclusively on generating a higher networkindependent value based on quality issues (McIntyre and Subramaniam, 2009). ${ }^{2}$ Network value has been defined as "the value stemming from other consumers already using the product" and it "is the reflection of the benefits associated with a large cohort of fellow adopters (installed base) for the product" (McIntyre and Subramaniam, 2009:1496). As a consequence, network value directly depends on the size of the installed base. The higher the number of users of a network, the higher the interaction possibilities between its members and, thus, the greater the utility they receive from belonging to that network.

It is necessary to note that network value is not merely the size of the installed base. Network value must also take into account the existence of network effects, which make it important for users to consume the product within a community. McIntyre and Subramaniam (2009) recognize that the relationship between the installed base and network value is not linear but depends on the strength of network effects or network intensity, which can be defined as the relative value generated by network size for the consumer. Thus, network value is a growing function of both network size and network intensity.

Network intensity depends on variables such as the product design (McIntyre and Subramaniam, 2009), the stage of the product life cycle at which users adopt the product (Farrell and Klemperer, 2007), ${ }^{3}$ the value of rival networks (Shapiro and Varian, 1998) ${ }^{4}$ and 
L. Fuentelsaz, E. Garrido and J.P. Maicas (2012).

A strategic approach to network value in network industries (JOM, Forthcoming)

the existence of local network effects (Suarez, 2005). For example, the importance that users confer to the existence of other users consuming the same good is higher in communication markets than in the videogames industry (Shankar and Bayus, 2003). Early adopters of a technology tend to obtain a higher utility from the existence of other users than late adopters (Farrell and Klemperer, 2007). Users take into consideration the number of users who consume the product of rival incompatible networks (Shapiro and Varian, 1998). They do not confer the same importance to the network as a whole because they achieve more utility by interacting with only part of it - friends or family, for example - (Birke and Swann, 2006; Suarez, 2005).

Due to possible economic and technological incompatibility between two firms' services or products (García-Mariñoso, 2001; Grajek, 2010), network effects often appear linked to the users of a given firm instead of being linked to the installed base of the industry as a whole. ${ }^{5}$ When the installed base of a firm grows, so does the network value of that firm as a result of network effects. But the extent of this growth of network value when the installed base increases will depend, precisely, on the network intensity.

\section{The Antecedents of Network Value: Expectations, Coordination and Compatibility}

It is important to identify the circumstances under which network effects lead to a reinforcement of network value. The literature on network industries has highlighted three main elements that interplay with network effects and allow a reinforcement of installed base and, thus, of network value: users' expectations, users' coordination and compatibility among competing networks (Katz and Shapiro, 1994).

The management of expectations has received attention from extant literature (Chacko and Mitchell, 1998; Eisenmann, 2006; Shapiro and Varian, 1998). The current installed base of a firm affects users' expectations about which firm will dominate the market in the future 
L. Fuentelsaz, E. Garrido and J.P. Maicas (2012).

A strategic approach to network value in network industries (JOM, Forthcoming)

(Brynjolfsson and Kemerer, 1996; Farrell and Saloner, 1986). Users prefer to consume goods and services from a firm with a larger installed base (Kim and Kwon, 2003; Birke and Swann, 2006). As a consequence, expectations are important because, if consumers believe a firm will dominate the market, then it will (Katz and Shapiro, 1985).

Given that expectations condition the size of the installed base, firms have strong incentives to launch signals to influence user expectations about their future network dominance. These signals can be quantitative or qualitative. Among the former, we can mention the size of the installed base (Kim and Kwon, 2003) or the early achievement of a large market share (Brynjolfsson and Kemerer, 1996). Qualitative signals include brand value or reputation (Katz and Shapiro, 1994) or the preannouncement of a new product or service that is not yet in the market, as in the case of the battle between Div-X and DVD (Dranove and Gandal, 2003).

While expectations have an individualist orientation, coordination requires a plural action. Users' coordination implies that several users join a system that allows them to interact with one another (Katz and Shapiro, 1994). When there are other incompatible networks, coordination of all users in a market to the same network is difficult for several reasons: confusion about what other people will do, different expectations about the dominant network, fear of taking the first decision, etc. Farrell and Klemperer (2007) use the term inertia to refer to a possible instrument that drives coordination. Inertia arises because later adopters choose a firm with a larger installed base even though there are better options. This literature has also referred to inertia as bandwagon effects, and this concept assumes that users tend to do the same thing as others (Liebenstein, 1950; Rohlfs, 2001). It means that consumers are conformists because they have a "desire to join the crowd" (Grajek, 2010). Examples of how inertia can determine the standard chosen by the industry even though it is 
not the best option are the QWERTY keyboard (David, 1985) or the light water technology for nuclear power reactors (Cowan, 1990).

The third element in network industries is compatibility. Compatibility arises when the products of different firms can be used together (Katz and Shapiro, 1985). In these situations, the scope of the users' network includes the installed base of the reference firm as well as the base of compatible industry competitors (Grajek, 2010). Users will prefer compatibility because it offers them greater communication possibilities. Incompatibility prevents firms from achieving a maximum network size since users are fragmented in different networks and are not able to interact between them. In the presence of incompatibility, the user's perceived utility will be lower (Katz and Shapiro, 1994; Lee and Mendelson, 2007) and, thus, network value will also decrease.

Expectations and coordination have to do with users' behavior whereas compatibility is a firm or policy decision. Compatibility is preferred by small rivals. It is a less risky option for entering into a market and allows them to exploit the network effects that come from the larger installed bases of their rivals. Therefore, compatibility often neutralizes the competitive advantage of a large network (Farrell and Klemperer, 2007). On the contrary, larger competitors with a strong reputation or brand value prefer incompatibility in order to deter the entry of new rivals (Katz and Shapiro, 1994). However, incompatibility is also a risky option because users may not have so much trust in a new network (Katz and Shapiro, 1985). Sometimes the regulator decides to make compatibility obligatory among networks in order to increase social welfare and avoid the dominance of a less efficient technological standard in the market due to path dependency. This is the case, for instance, of the mobile communications industry in Europe, where the European Union decided to establish a supranational and common standard among networks (Fuentelsaz, Maicas and Polo, 2008; Gruber, 2005). 
L. Fuentelsaz, E. Garrido and J.P. Maicas (2012).

A strategic approach to network value in network industries (JOM, Forthcoming)

An example of the trade-off between large and small companies with respect to compatibility can be found in the competition between Microsoft and Apple. In recent years, Apple has designed a strategy based on increasing the compatibility between its computers and Windows applications. Apple has opted for compatibility to increase users' utility and reduce the obstacles they perceive if they choose its network. The increase in network value derived from being able to exchange compatible information with other Macintosh users has put Apple in a better competitive position. Microsoft, on the contrary, has made no effort to be compatible with other operating systems because it has the largest network value and the positive feedback helps it to continue growing.

This preference of small firms for compatibility can also be found in our research setting. Big operators tend to establish a higher gap between on-net and off-net calls, increasing the (economic) incompatibility with rivals' networks. On the contrary, small operators offer very similar conditions to their users regardless of the destination of their calls. For instance, Ofcom (2009) determined that Three and T-Mobile, two of the smallest operators in United Kingdom, were the only operators which charged the same price for on-net and off-net calls in both prepaid and postpaid plans.

\section{Strategic Choices, Network Value and Performance}

First-mover advantages (FMA) and network value. The study of FMA has been one of the cornerstones of the strategy and management literatures (Carpenter and Nakamoto, 1989; Kalyanaram and Urban, 1992; Lambkin, 1988; Lieberman and Montgomery, 1988). FMA have also played an important role in the context of network effects research (Farrell and Klemperer, 2007; Katz and Shapiro, 1994; Srinivasan, Lilien and Ragaswamy, 2004).

In markets with network effects, firms will be interested in building a large installed base as an indicator of future dominance (Brynjolfsson and Kemerer, 1996). These efforts will be 
L. Fuentelsaz, E. Garrido and J.P. Maicas (2012).

A strategic approach to network value in network industries (JOM, Forthcoming)

especially important in the early stages of competition. Firms that enter the market earlier will increase their possibilities of achieving an advantageous position (Arthur, 1990). As a result of early entry, the firm will be able to determine the dominant design of the product (Arthur, 1989) and influence the formation of users' preferences (Carpenter and Nakamoto, 1986) given that pioneers usually receive disproportionate attention from consumers because of the newness of their product (Lieberman and Montgomery, 1988). As a consequence, we suggest that a firm with a longer time in the market has a larger network value because it has had more time to make efforts in the management of users' expectations through the achievement of an early installed base before the entry of rivals.

It is also important to note that the inertia that we have discussed before will lead late users to choose the firms with a larger installed base. If a pioneer is able to convince early users about its dominance, late consumers will prefer to follow them into the same network and the pioneers' product will become the standard in the industry (Schmalensee, 1982; Carpenter and Nakamoto, 1986; Farrell and Klemperer, 2007). Having achieved a leading position, the pioneers' installed base will persist because of the difficulty of modifying users' preferences (Lieberman and Montgomery, 1988). This is the main idea of the bandwagon effects we have previously referred to. Accordingly, we expect that time in the market increases the firms' opportunities to influence user expectations about their networks. As a result of inertia, the network value of a firm that has been in the market a long time will be higher.

H1. The time that a firm has been operating in the market has a positive effect on its network value

Internationalization and network value. The literature has tended to study markets with indirect network effects in which diversification in complementary products plays an 
L. Fuentelsaz, E. Garrido and J.P. Maicas (2012).

A strategic approach to network value in network industries (JOM, Forthcoming)

important role (Hill, 1992; Schilling, 2002; Tanriverdi and Lee, 2008). However, less attention has been paid to other growth strategies in markets with direct network effects such as international diversification, especially when international network effects operate (Gruber and Verboven, 2001).

Internationalization is, nowadays, an important topic of discussion because many firms are trying to compete globally (Barkema and Drogendijk, 2007; Grant, 2005). As a result, not only are firms present in various countries, but customers also "think" globally. National and regional preferences are disappearing as a consequence of a process of homogenization derived from technology, communication and travel (Grant, 2005). This means that customers are becoming more and more familiar with international firms and their brands. The internationalization of firms could be a means of attracting the interest of users in different countries since users value established brands (Lane and Jacobson, 1995). We would expect the internationalization of a firm to influence its network value through its impact on expectations, coordination and perceived compatibility.

First, internationalization can be understood as a signal that influences users' expectations about future network dominance. There is an advantage for a firm entering a new local market when it has a wide international scope. It will have a larger perceived installed base compared to new domestic firms. Accordingly, the literature has highlighted the existence of international network effects through which "the utility of each consumer rises with the increase in the number of consumers who use the same brand regardless of whether they live in their own country or abroad" (Shy, 2001: 92). Thus, an international firm will reinforce the positive expectations of users about its future survival on the basis of being present in other countries and the familiarity of domestic users with its brand through the leverage of international network effects. 
L. Fuentelsaz, E. Garrido and J.P. Maicas (2012).

A strategic approach to network value in network industries (JOM, Forthcoming)

Consequently, we also expect that internationalization will facilitate coordination through international bandwagon effects. If users know that a firm has been chosen by users in other countries, inertia could lead them to make the same choice in their home market. Users will have more incentives to choose the international firm, replicating the choices of foreign users, since they want to imitate global trends (Grant, 2005). Firms with an international presence try to create interdependences among different countries, which result in a close relation between the competitive position in one national market and the competitive position in others (Ghoshal, 1987: 425).

Finally, it is also important to note that compatibility among inter-country networks is necessary to influence users' decisions. In the case of mobile telecommunications, Gruber and Verboven (2001) suggest that, with GSM wide-ranging international roaming, users may have greater incentives to adopt mobile communications since they benefit from international network effects. The firms that offer comparable, seamless and compatible services across international markets will obtain the commitment of users that exchange information internationally (Sarkar, Cavusgil and Aulakh, 1999).

As a consequence, we expect that the presence of the firm in various countries will create a larger network value through its influence on expectations and coordination as firms try to compete globally in order to attract users across countries. Compatibility will reinforce the influence of internationalization on network value by allowing international network effects.

\section{H2. The level of internationalization of a firm has a positive effect on its network value}

Switching costs and network value. Switching costs are present in all network markets and their management has a strategic dimension (Gomez and Maicas, 2011; Shapiro and Varian, 1998). Consumer switching costs appear when "consumers who have previously purchased from one firm have (or perceive) costs of switching to a competitor's product, 
L. Fuentelsaz, E. Garrido and J.P. Maicas (2012).

A strategic approach to network value in network industries (JOM, Forthcoming)

even when the two firms' products are functionally identical" (Klemperer, 1995: 515). The literature has highlighted how switching costs can increase the market power of a firm, allowing it to create entry barriers (Karakaya and Stahl, 1989; Kerin, Varadarajan and Peterson, 1992) and obtain abnormal returns that allow the firm to achieve sustainable competitive advantages (Amit and Zott, 2001; Klemperer, 1987; Lieberman and Montgomery, 1988; Schmalensee, 1982). However, the effectiveness of this mechanism as a basis for sustainable competitive advantages in information markets has been questioned (Mata, Fuerst and Barney, 1995). The effect of high switching costs may result in the loss of network value through their impact on expectations and coordination, as we argue below.

As mentioned before, network value depends on the installed base and users' utility in the presence of network effects. While switching costs have been used as an instrument to maintain the installed base by reducing customers' desire to leave their current provider (Burnham, Frels and Mahajan, 2003), these costs reduce users' utility (Maicas, Polo and Sese, 2009) not only because switching from one provider to another is costly but also because users perceive the threat of opportunistic firm behavior that could lead to future price increases in a bargain-then-rip-off pricing strategy (Farrell and Klemperer, 2007). It is not surprising that this expected opportunism leads users to form a negative image of the firm (Mata et al., 1995). Since potential users tend to form expectations about the future survival of the firm not only with quantitative signals such as the installed base, but also with qualitative signals like brand image or reputation (Katz and Shapiro, 1994), they will be reluctant to choose a firm with high switching costs. Frels, Shervani and Srivastava (2003) comment that a network of previous adopters is believed to influence adoption among nonadopters by providing opinions by word of mouth and observation. The negative experience of the current installed base will result in the formation of negative expectations about a firm network with higher switching costs and will prevent user coordination with this network, 
L. Fuentelsaz, E. Garrido and J.P. Maicas (2012).

A strategic approach to network value in network industries (JOM, Forthcoming)

leading to a negative impact on network value. Mata et al. (1995: 490) explain that "the value of opportunities lost because of a reputation for exploiting captured customers can be much larger than the value extracted from those captured customers".

Switching costs are especially high when networks are incompatible. In particular, technological incompatibility is one of the main drivers of consumer switching costs (GarciaMariñoso, 2001). It is costly to abandon a network because of learning costs or loss of communication possibilities with current users. Economic or artificial incompatibility also arises when the costs of communication among users are cheaper if they belong to the same network (Grajek, 2010). In this case, economic incompatibility increases the pecuniary switching costs derived from the higher costs of communicating with users of the previous network. Thus, incompatibility will reinforce the negative effect of switching costs on utility and, consequently, on network value.

\section{H3. Switching costs have a negative effect on firm network value.}

Network value and performance. In network industries, current performance is strongly dependent on past events (Farrell and Klemperer, 2007; McIntyre and Subramaniam, 2009). This is the so-called positive feedback that "reinforces that which gains success or aggravates that which suffers loss" (Arthur, 1996: 100).

The literature has suggested that a continuous increase in network value is followed by an increase in the willingness to pay to have access to that network (Doganoglu and Grzybowski, 2007) and the subsequent decrease of the marginal costs of each information interchange (Arthur, 1990). This is because the value does not lie in the product itself, but in the size and intensity of the network (De Palma and Leruth, 1996; Grajek, 2010). The product is more valuable as more people use it (Doganoglu and Gryzbowski, 2007). While a greater network value permits a higher price, marginal costs decrease as more and more information 
ties take place. In spite of a large initial investment, the marginal costs of producing an additional exchange are relatively cheap (Shapiro and Varian, 1998) because information markets are knowledge-based (Arthur, 1990).

We expect that a firm with a larger network value will also obtain a higher marginal net income from each information exchange derived from a higher price and lower marginal costs. Thus, performance will be positively related to network value.

H4. Network value has a positive effect on firm performance.

\section{DATA}

\section{Research Setting: the European Mobile Communications Industry}

The European mobile communications industry represents a large, fruitful and growing portion of Europe's economy. This industry has become an important source of wealth in Europe. For instance, the telecommunications industry made up $2.83 \%$ of the GDP at the end of 2007, whereas, for example, agriculture constituted 1.82\% (World Bank Group, 2010). The Financial Times Global 500 Index (2011) shows that 11 of the 50 largest firms in the world belong to network industries, five of them being mobile operators of which two, moreover, are European (Vodafone in the United Kingdom and Telefonica in Spain). Furthermore, the industry has grown impressively in recent years: its average penetration rate in Europe increased from around $30 \%$ at the end of 1998 to slightly over $120 \%$ in the middle of 2008 (Merrill Lynch, 2010).

Telecommunications, in general, and mobile communications, in particular, are paradigmatic examples of industries with direct or pure network effects (Doganoglu and Grzybowski, 2007; Srinivasan et al., 2004). Srinivasan et al. (2004) rate this industry among the highest in a list of 45 goods and services that are believed to be intensive in network 
L. Fuentelsaz, E. Garrido and J.P. Maicas (2012).

A strategic approach to network value in network industries (JOM, Forthcoming)

effects. For this reason, this industry has been chosen in previous research to develop empirical analysis in studies where network effects are important (Birke and Swann, 2006, 2010; Corrocher and Zirulia, 2009; Doganoglu and Gryzbowski, 2007; Maicas, Polo and Sese, 2009).

The literature emphasizes the role of expectations and users' coordination on users' choice of mobile network (Doganoglu and Grazybowski, 2007; Gandal, 2002; Church and Gandal, 2005). It has been shown that, among other factors, the total installed base of an operator plays an important role in users' expectations and coordination (Birke and Swann, 2006). Because of this, small operators in European markets may fail if they do not achieve a minimum critical mass to influence users' expectations and coordination (Economides and Himmelberg, 1995).

Incompatibility issues have been especially remarkable in the European context in determining the scope of networks and understanding the existence of tariff-mediated or artificial network effects. As previously mentioned, the scope of networks is dependent on technological and economic compatibility. With regard to technological compatibility, in 1984, the European Commission, through the Group Special Mobile (GSM), encouraged the development of a common technological standard which allowed mobile services within national and international networks. As a consequence, a user can employ his/her handset to make calls to the mobile phones of any firm in the country without technological restrictions and can use the same handset in any European country thanks to international roaming agreements.

Nevertheless, in spite of this technological compatibility guided by supranational authorities, an economic incompatibility between firms' networks comes from the price discrimination between on-net and off-net calls. It generates what the literature has called tariff-mediated network effects, which appear at firm-level (Grajek, 2010; Laffont, Rey and 
Tirole, 1998). Users prefer to belong to a larger network to reduce the probability of making off-net calls and benefit from lower on-net prices.

Price discrimination between on-net and off-net calls has been identified by different authorities, including the Commission of the European Communities and Ofcom (the UK regulator), in most European countries (e.g., United Kingdom, Spain, Portugal and Germany). ${ }^{6}$ Although authorities have considered price discrimination to be an issue, only Ofcom quantifies it. A report from 2007 observes that, between 2002 and 2006, price discrimination in the United Kingdom decreased from 17.5 to 5.4 pence per minute. In spite of the decrease, price discrimination still exists in the market (Ofcom, 2011).

Our research setting is appropriate for analyzing the strategic actions described in the hypotheses above. First, entry timing strategies have been analyzed in the mobile communications industry and the results show that being the first into the market does pay (Bijwaard, Janssen and Maasland, 2008; Gomez and Maicas, 2011; Usero and Fernandez, 2009). Second, European mobile operators started their expansion around the world in the last years of the $20^{\text {th }}$ century. The result of this internationalization process is that several groups, such as Vodafone, Teléfonica and T-mobile, have evolved from being mostly local operators to become highly internationalized. The internationalization of these operators has been studied in previous literature (Curwen and Whalley, 2008; Gerpott and Jakopin, 2005; Graack, 1996). Finally, switching costs have been found to be linked to the industry and their impact on firm performance has been analyzed (Shy, 2001; Viard, 2007).

\section{Sample}

Our database includes the whole population of mobile communications providers that operated in twenty European markets between the last quarter of 1998 and the second quarter 
L. Fuentelsaz, E. Garrido and J.P. Maicas (2012).

A strategic approach to network value in network industries (JOM, Forthcoming)

of $2008 .^{7}$ This long period is important because our sample does not suffer from survival bias. We should clarify that our data refers to the activity of each operator in each country because, in mobile communications, competition takes place within national markets. ${ }^{8}$ Our information comes from multiple sources but the main one is the Merrill Lynch Global Wireless Matrix. This publication provides quarterly information on several of the variables of interest such as the name of the firms, the number of subscribers, the number of firms per market and their performance. We have also collected information about the date of entry of the firms and their shareholder structure, mainly from industry reports and the corporate information of the firms.

\section{Measurement of Variables}

Network value. The literature offers different approaches to the measurement of the network value of a firm. Swann (2002) describes the traditional ways to determine it. The simplest way, Sarnoff's Law, measures network value through the size of the installed base, $n$ (Reed, 1999).

Nevertheless, we have argued that network value does not only depend on the size of the installed base. Our interest lies in network industries with direct network effects. In our industry, the possibilities of communication increase with the number of users consuming the good and, thus, their perceived utility grows. According to Church and Gandal (2004:3), "an adopter's link to the network has no value except to facilitate the transmission of information to, and from, other adopters". Farrell and Klemperer (2007) suggest that the users of a communication network gain directly when other users adopt it because they have more opportunities for interaction with peers. Stabell and Fjelstad (1998: 431) also consider that in network industries "the dependency among customers is the main product delivered". Thus, a second option for measuring network value is to proxy it by the number of possible 
communication ties that exist among the users of the same network. This is known as Metcalfe's Law and is measured as $n^{*}(n-1)$. With this measure, we mainly focus on the possibilities of connectivity between users (Ross, 2003).

Metcalfe's Law has been criticized for giving the same importance to all users (Grajek, 2010; Briscoe, Odlyzko and Tilly, 2006). As mentioned in the second section, network intensity determines the relationship between network size and network value (McIntyre and Subramaniam, 2009). This intensity depends on several factors, including the stage of the product-life cycle in which users adopt the product. Farrell and Klemperer $(2007: 1975)$ suggest that early adopters are more important than later adopters, first adopters having an "excess early power" to determine the dominant network in the future. Early adopters generate more network value for the firm than later ones because of the inertia operating in these markets. For this reason, the literature has suggested a third approach that considers a decreasing marginal network value as $n * \log (n)$, known as Zipf's Law (Briscoe et al., 2006). This expression acknowledges both the idea of users' connectivity and the differences between early and late adopters. We will use this approach as our first measure of network value (NETWORK VALUE).

However, Zipf's Law only considers the firm's own network size in the calculus of the network value of the firm. That is, with the same number of users, network value will be the same in different markets independently of the market characteristics (number of rivals, differences in size...). This does not introduce any bias into the calculus of network value if there is total compatibility among networks. Nevertheless, in mobile communications there is some degree of incompatibility among networks (Grajek, 2010). In this industry, economic incompatibility is reflected in the differences between on-net and off-net tariffs. For this reason, we propose an alternative measure of network value that tries to overcome some of the inconveniences of Zipf's Law by taking into account the particular conditions of each 
L. Fuentelsaz, E. Garrido and J.P. Maicas (2012).

A strategic approach to network value in network industries (JOM, Forthcoming)

market (e.g., number of rivals and differences in size) and, thus, the existence of different network intensities in different networks. With this measure, we try to determine which firms are capable of leveraging more intensive network effects or, in other words, which firms are more attractive to users depending on market structure (McIntyre and Subramaniam, 2009).

We are going to offer a very simplistic but illustrative example of our previous reasoning. Consider two markets, $\mathrm{A}$ and $\mathrm{B}$, with two firms, firms 1 and 2, operating in each and the market shares shown in Table 1.

Insert Table 1 about here

In the two markets, firm 1 has the same network value using Zipf's Law $\left(1,200^{*} \log (1,200)\right)$ and offers more communication possibilities than firm 2. However, users of firm 1 in market A have twice the probability of making off-net calls (40\%) than users of firm 1 in market B $(20 \%)$. Following the anecdotal evidence in the industry, there is a tendency in mobile communications to penalize off-net calls through a higher price than on-net calls (Birke and Swann, 2006; Grajek, 2010). Thus, users of firm 1 in market B receive a higher utility from having selected firm 1 instead of firm 2 than in network A. In other words, the network of firm 1 in market $\mathrm{B}$ is more attractive than in market $\mathrm{A}$ and can leverage more intensive network effects, because of the price differences between on-net and off-net calls. ${ }^{9}$

The higher the expected probability of making on-net calls over the probability of making off-net calls, the more attractive the network of a particular firm is. We propose amending Zipf's Law with the ratio of on-net over off-net call probabilities (prob ${ }_{\text {on-net }} / \mathrm{prob}_{\text {off-net }}$ ), assuming that the calls from one network to another are proportional to the sizes of the installed bases. In this way, we reward a firm that has achieved a larger installed base in comparison with its direct rivals in its specific market since the probability of users that have 
chosen it supporting an additional cost derived from making off-net calls is inferior (prob ${ }_{\text {on-net }}$ $>$ prob $_{\text {off-net). }}$. Likewise, we penalize those firms that have a lower network size, with a higher probability of their users making off-net calls and, thus, supporting higher call costs (prob ${ }_{\text {on- }}$ net $<$ prob $_{\text {off-net }) .}$

In order to calculate the expected probability of making on-net calls over off-net calls ( prob $_{\text {on-net }} /$ prob $_{\text {off-net }}$ ), we borrow the example provided by Birke and Swann (2006) who develop a likelihood matrix that represents the pattern of calls between rival networks in a given market. Let's assume that there are four operators $(i=1, \ldots, 4)$ competing in a market and that the market share of each is given by $m_{i}$. Assuming that there are no price differences between on-net and off-net calls and accepting that the calls from one network to another are proportional to the sizes of the installed bases, the expected call probability among users of different networks is given by the product of their respective market shares as shown in the following matrix (Table 2):

Insert Table 2 about here

The probability of making on-net calls (prob ${ }_{\text {on-net }}$ ) is given by the elements of the matrix diagonal $\left(m_{i} m_{i}\right)$, whereas the off-diagonal elements $\left(m_{i} m_{j}\right)$ refer to off-net call probability (prob ${ }_{\text {off-net }}$ ) between networks for each firm. Thus, the probability of making on-net calls over off-net calls for each firm $\mathrm{i}$ in a market with $\mathrm{M}$ companies is given by the ratio:

$$
\frac{m_{i} m_{i}}{\sum_{j=1}^{M-1} m_{i} m_{j}}=\frac{m_{i}}{1-m_{i}} \quad[\mathrm{i} \neq \mathrm{j}]
$$

By modifying Zipf's Law with this ratio, the adjusted network value (NETWORK VALUE') is expressed as: 
L. Fuentelsaz, E. Garrido and J.P. Maicas (2012).

A strategic approach to network value in network industries (JOM, Forthcoming)

$$
n_{i} \log \left(n_{i}\right) \frac{m_{i}}{1-m_{i}}
$$

As a consequence, the adjusted network value will be higher when: a) there is a larger installed base that allows greater communications possibilities among current users of the network (network size dimension of network value); b) there is a larger difference between the network sizes of the reference firm and its rivals, which gives it a competitive advantage to leverage more intensive network effects and make its network more attractive to potential users (network intensity dimension of network value).

Performance (PERFORMANCE). Firm profitability is measured through EBITDA (Earnings Before Interest, Taxes, Depreciation and Amortization) divided by the total revenues of the firm. Both EBITDA and revenues are calculated for each firm in each national market.

Time in the market $(T I M E)$. Different concepts of pioneering have been used when modeling first-mover advantages. Srinivasan et al. (2004) consider the pioneer to be the first firm to commercialize a new product. Lieberman and Montgomery (1988) suggest some alternative measures such as the numerical order of entry, rates of company survival, duration of advantages and time from pioneer entry. Brown and Lattin (1994) suggest time in the market as an adequate measure of FMA.

Our variable counts the number of months that a firm has been operating in digital wireless technology (GSM). The decision to take GSM as the starting point of the market responds to the scarce acceptance of analogical technology. For example, in the ten years between 1980 and 1990 when analogical technology was available, the rate of penetration only grew from $0.0 \%$ to $0.92 \%$. Accordingly, we assume that the market was almost nonexistent before the introduction of the digital generation. 
L. Fuentelsaz, E. Garrido and J.P. Maicas (2012).

A strategic approach to network value in network industries (JOM, Forthcoming)

International presence (INTERNATIONALIZATION). The literature has traditionally measured international diversification through variables such as international sales over total sales (Strike, Gao and Bansal, 2006), number of workers abroad (Brock, Yaffe and Dembovsky, 2006), sales in a country weighted by the importance of this market (Hitt et al., 1997), number of international subsidiaries (Barkema and Drogendijk, 2007; Strike et al., 2006) and the number of countries in which the firm operates (Brock et al., 2006). In this study, we have chosen the number of countries in which the firm is present with an ownership of above $50 \%$. Our theoretical rationale is that to influence network value, the level of firm internationalization has to be in the users' minds. Therefore, the main reason to choose the number of countries in which the firm is operating is that this information is known by the user, while other alternatives previously mentioned - number of workers abroad, international sales... - are not easy for the user to identify.

More importantly, the criteria of $50 \%$ of ownership has been selected to assure that the international group considers the national operator as part of the core organization and that international network effects can develop. After reviewing annual reports of international groups in Europe, we have observed that there has been a gradual acquisition of the ownership of national operators, from minority to majority, by international groups. Only after acquiring more than $50 \%$ of the ownership, have international groups included the national companies as part of their organizational chart. Moreover, for international network effects to exist, users must be able to recognize the same firm operating in different markets (Shy, 2001), so the international groups in Europe have started to build global brands. The rebranding of acquired operators by international groups has only taken place after the acquisition of an ownership above $50 \%$.

Switching costs (SWITCHING COSTS). According to the existing literature, there is an important gap between the theoretical and the empirical research on switching costs (Stango, 
2002; Grzybowski, 2007; Chen and Hitt, 2007; Viard, 2007). Only a few articles have tried to properly measure their magnitude. We closely follow the model proposed by Shy (2002). This author develops a method for estimating switching costs among firms in a context where we only need to have information about prices and market shares. It is important to note that Shy's method has been previously used in the literature with very similar purposes to ours (Carlsson and Löfgren, 2006; Gomez and Maicas, 2011; Krafft and Salies, 2008).

Shy (2002) considers a market with two firms (A and B). Consumers are assumed to be distributed between the firms so that, initially, $N_{A}$ consumers have already purchased brand $A$ (type $a$ consumers) and $N_{B}$ consumers have already purchased brand $B$ (type $b$ consumers). $p_{A}$ and $p_{B}$ represent firm $A$ and $B$ prices, respectively, and $s$ is the cost of switching brands. The utility $U_{A}\left(U_{B}\right)$ for a user who is now buying from $A(B)$, can be written as:

$$
U_{A} \stackrel{\text { def }}{=} \begin{cases}-p_{A} & \text { staying with brand A } \\ -p_{B}-s & \text { switching to brand B }\end{cases}
$$

The number of subscribers for A (B), $n_{A}\left(n_{B}\right)$ in the following period is given by,

$$
n_{A}= \begin{cases}0 & \text { if } p_{A}>p_{B}+s \\ N_{A} & \text { if } p_{B}-s \leq p_{A} \leq p_{B}+s \\ N_{A}+N_{B} & \text { if } p_{A}<p_{B}-s\end{cases}
$$

If we assume that the firm's production costs are zero, the profit, $\pi_{A}\left(\pi_{B}\right)$, of each firm is:

$$
\pi_{A}\left(p_{A}, p_{B}\right)=p_{A} n_{A}
$$

Shy (2002) postulates that the pair of prices that solve the problem for firms $A$ and $B$ and constitute a Nash-Bertrand equilibrium are:

$$
p_{A}=\frac{\left(N_{A}+N_{B}\right)\left(N_{A}+2 N_{B}\right) s}{\left(N_{A}\right)^{2}+N_{A} N_{B}+\left(N_{B}\right)^{2}} \quad \text { and } \quad p_{B}=\frac{\left(N_{A}+N_{B}\right)\left(2 N_{A}+N_{B}\right) S}{\left(N_{A}\right)^{2}+N_{A} N_{B}+\left(N_{B}\right)^{2}}
$$


Shy (2002) extends the model to a multi-firm industry. He considers the possibility of more than two firms, each indexed by $i, i=1, \ldots, M$ (firms in order of higher to lower market share). The expressions for switching costs in a multi-firm industry are:

$$
s_{i}=p_{i}-\frac{N_{M} P_{M}}{N_{i}+N_{M}}, \text { if } \mathrm{I} \in\{1, \ldots, \mathrm{M}-1\} \text { and } s_{M}=p_{M}-\frac{N_{1} P_{1}}{N_{1}+N_{M}}
$$

In this model, it is important to have a precise measure of sizes and prices. Sizes are incorporated into the switching costs function through the market shares of the firms. A more controversial issue is to define prices in mobile communications. Prices usually vary depending on the characteristics of the user, the receiver of the phone call (on-net $v s$. off-net calls) or the time of the day. To solve this problem, Shy (2002) derives prices from the Average Revenue per User (ARpU) in his calculation of switching costs in mobile communications in Israel. Furthermore, the use of $\mathrm{ARpU}$ as a proxy of prices is also motivated by "its widespread use in industry and regulatory circles" (McCloughan and Lyons, 2006:523). An additional advantage of ARpU is that it makes comparisons among countries possible.

Control variables. Besides the variables described to test the proposed hypotheses, our model also controls for additional covariates. First, we control for the population in each national market (POPULATION), which is expected to have a positive relationship with network value and performance because the communication possibilities in each national market will be higher. Given that population can be considered as a proxy of the potential size of the industry, the introduction of this variable also allows us to control for the existence of industry-level network effects. We also control for country-specific rivalry by taking into account the number of firms operating in each market (FIRMS). This variable is expected to negatively affect firm performance. However, the relationship between the number of firms and network value is not so clear. A higher number of firms would probably result in smaller 
L. Fuentelsaz, E. Garrido and J.P. Maicas (2012).

A strategic approach to network value in network industries (JOM, Forthcoming)

networks, decreasing network value. But the increase in the number of firms could also constitute an improvement in the competitiveness of the market and price reductions. It might enhance users' utility and technology adoption, with a subsequent increase of network value. Finally, the model also includes year dummies to control for time-specific influences (YEAR).

\section{Descriptive Statistics}

Descriptive statistics are shown in Tables 3 and 4. The first includes the determinants of the network value model and the second those of the profitability model. The existence of missing values in our dependent variables implies that we are left with 2,032 observations for the network value model and 1,991 for the profitability model.

As can be seen in Table 3, the average value of our first measure of network value (NETWORK VALUE) is 15.28 , while it is 9.25 for the adjusted network value (NETWORK $\left.V A L U E^{\prime}\right)$. Moreover, the average European firm has been operating in the market for nine years (107.5 months) at the end of the study range, has established a presence in 8 countries around the world and has positive switching costs of around 17 euros per user. The average number of firms per market is 3 . When we analyze the correlation matrix, we can observe that both network value and adjusted network value are highly correlated with population and with time in the market. Nevertheless, the correlation among the independent variables is moderate. Table 4 shows that the performance is better than the performance in the previous period, exhibiting a positive relationship with network value but a negative one with population and number of firms.

Insert Table 3 about here 
Insert Table 4 about here

\section{METHODS}

In this section, we develop two econometric models that help to describe and empirically examine the determinants of network value and the impact of the latter on firm performance. First, we separately present the network value and firm profitability models. After that, we discuss the procedure to estimate the system of equations.

\section{Network Value Model}

We model the network value of firm $\mathrm{i}$ (competing in market $\mathrm{k}$ ) in period $\mathrm{t}$ (NETWORK $\left.V A L U E_{\mathrm{ikt}}\right)$ as a function of the time that firm $\mathrm{i}$ has been competing in the market $\left(T I M E_{\mathrm{ikt}}\right)$, the international presence of firm i (INTERNATIONALIZATION $\mathrm{ikt}_{\mathrm{ik}}$ ), and the switching costs

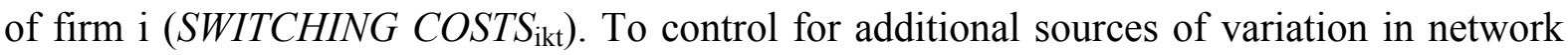
value, we introduce a set of control variables that include the population in market $\mathrm{k}$ in period $\mathrm{t}($ POPULATION $\mathrm{kt})$, the number of firms competing in market $\mathrm{k}$ in period $\mathrm{t}\left(F I R M S_{\mathrm{kt}}\right)$ and year effects (YEAR). We represent the network value model in Equation (4.1) as follows:

NETWORK VALUE $E_{\mathrm{ikt}}=\beta_{1}$ TIME $_{i k t}+\beta_{2}$ INTERNATIONALIZATION $_{i t}+\beta_{3}$ SWITCHING COSTS $_{i k t}$

$$
+\beta_{4} \text { POPULATION }_{k t}+\beta_{5} \text { FIRMS }_{k t}+\beta_{6} \text { YEAR }+\varepsilon_{i k t}
$$

\section{Profitability Model}

Consistent with the proposed conceptual framework, we relate the network value of the firm to performance outcomes. We model the performance of firm $\mathrm{i}$ in market $\mathrm{k}$ in period $\mathrm{t}$ 
L. Fuentelsaz, E. Garrido and J.P. Maicas (2012).

A strategic approach to network value in network industries (JOM, Forthcoming)

(PERFORMANCE $\left.E_{\mathrm{ikt}}\right)$ as a function of network value. Following previous literature, especially in industries with increasing returns where there is a path dependency from performance in previous periods, we control for past realizations of the dependent variable (PERFORMANCE $\left.E_{\text {ikt-1 }}\right)$. We also control for additional factors that potentially affect

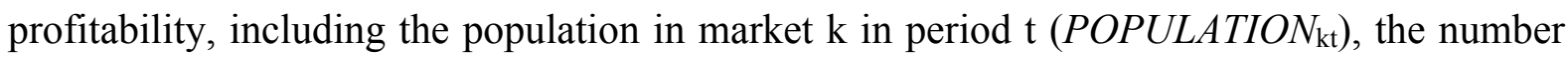
of firms in market $\mathrm{k}$ in period $\mathrm{t}\left(F I R M S_{\mathrm{kt}}\right)$ and time controls $($ YEAR).

PERFORMANCE $_{i k t}=\lambda_{0}+\lambda_{1}$ PERFORMANCE $_{i k t-1}+\lambda_{2}$ NETWORK VALUE $_{i k t}+\lambda_{3}$ POPULATION $_{k t}$

$$
+\lambda_{4} F I R M S_{k t}+\lambda_{5} Y E A R+\varphi_{i k t}
$$

\section{Estimation Procedure}

We estimate equations (4.1) and (4.2) as follows. We propose static panel estimators to explore the determinants of network value (Hypotheses 1 to 3 ). We estimate a fixed effect model where network value is the dependent variable. The fixed effects estimation method is used in longitudinal panel analyses and allows the unobserved individual effects to be correlated with the included variables (Greene, 2003). The existence of these individual effects has been tested by the Lagrange multiplier of Breusch and Pagan (1980) and the preference for fixed effects estimation over random effects derives from the test of Hausman (1978). However, dynamic panel estimators are considered for the profitability model (Hypothesis 4) since the lagged performance is introduced as the explanatory variable of the performance equation (4.2).

We test Hypothesis 4 by estimating a System Generalized Method of Moments model (System GMM), proposed by Arellano and Bover (1995) and fully developed by Blundell and Bond (1998). It is frequently used in profitability models in which current performance is highly conditioned by firm performance in the previous period. Jointly with the lagged 
L. Fuentelsaz, E. Garrido and J.P. Maicas (2012).

A strategic approach to network value in network industries (JOM, Forthcoming)

performance, we also include network value as a regressor to test the impact of our key element on firm performance.

\section{RESULTS}

\section{Strategic Choices and Network Value}

Table 5 reports the parameter estimated for the fixed effects models. All the equations present heteroskedasticity and autocorrelation consistent (HAC) estimates. To test our hypotheses, eight regressions with two dependent variables have been run: network value (NETWORK VALUE) from equation A.1 to A.4 and adjusted network value (NETWORK $V A L U E^{\prime}$ ) from B.1 to B.4. Equations A.1 and B.1 only include the control variables, while the remaining explanatory variables are added consecutively in a nested way, so that models A.4 and B.4 present the estimation that includes all the explanatory variables. The hypothesis that the independent variables are jointly equal to zero is rejected for both models, A.1 and B.1 $(\rho<0.01)$, as can be inferred from the F-test (not shown). Compared with equations with no explanatory variables, the full models, A.4 and B.4, show a significantly better fit.

Model A.2 shows that the variable time in the market presents a positive and highly significant effect, which supports Hypothesis 1: network value increases with the time that the firm has been operating in the market. Model A.3 adds the variable internationalization. Its value is also positive but non-significant, thus, Hypothesis 2 cannot be accepted ${ }^{10}$. Finally, model A.4 also includes the variable switching costs, with a negative and significant coefficient: the presence of switching costs decreases the network value, as proposed in

Hypothesis 3. The F-test, which compares different nested models, is also shown at the end of Table 5 and confirms that the estimation presented in column A.4 is the one that best fits our data. In this model, the global fit is quite satisfactory, with an R-squared around 0.6. In any 
L. Fuentelsaz, E. Garrido and J.P. Maicas (2012).

A strategic approach to network value in network industries (JOM, Forthcoming)

case, it is also important to note that the value of the coefficients of the main explanatory variables of the model remains highly stable in all the estimations.

With respect to the control variables, population in each national market has a positive and significant influence on network value in all models. This means that the total size of the market, proxied by population, is positively related to our dependent variable and reveals that the mobile communications industry also presents network effects at industry-level, which is consistent with previous findings (Kim and Kwon, 2003). The variable firms is significant only in the final model A.4. One possible explanation may be the low but positive correlation between firms and switching costs. When both are included in model A.4, they are significant. When the switching costs variable is dropped in model A.3, its impact on network value might be partially captured by the remaining variables. In this case, firms in equation A.3 may reflect the positive influence of firms on network value but also the negative one of switching costs on network value. This results in a reduction of the direct positive effect of firms on network value by the introduction of the negative effect of switching costs, making the final coefficient non-significant.

If we consider the set of models that use the adjusted network value as the dependent variable, the sign and significance of the main coefficients does not change. As can be seen in Table 5, time in the market increases adjusted network value and switching costs decrease it, supporting Hypotheses 1 and 3, respectively. Internationalization has no significant effect on network value, which means that Hypothesis 2 is not supported. These coefficients remain highly stable in all the estimations. As for the control variables, time dummies are globally significant and population preserves its positive and significant influence on network value. However, the variable firms loses its positive significance. The F-test confirms that model B.4 is the estimation that best fits our data. In this model, R-squared presents a value of 0.46 . Note that the measure of network value that takes into account the disutility perceived by the 
L. Fuentelsaz, E. Garrido and J.P. Maicas (2012).

A strategic approach to network value in network industries (JOM, Forthcoming)

existence of rival networks in the presence of economic incompatibility reduces the coefficients of the main explanatory variables although the sign of the relationship with network value does not substantially change.

Insert Table 5 about here

\section{Performance and Network Value}

The results of the estimations of the performance model are shown in Table 6. Model C. 1 introduces the control variables and the lagged performance, whereas models C.2 and C.3 add network value and adjusted network value, respectively. Our specification choice is based on a System GMM with first differences, a one-step estimation that is robust to heteroskedasticity and takes into account the potential endogeneity of the explanatory variables. To assess the validity of the System GMM estimators, we run the Arellano-Bond test for first-order and second-order serial correlation. Table 6 reports the significant $\mathrm{m} 1$ and insignificant $\mathrm{m} 2$ serial correlation statistics. This indicates that there is no second-order correlation in the level of residuals. The Hansen test is also reported and its non-significance validates the robustness of our estimations.

Lagged performance has a positive and significant influence on performance with a coefficient that is highly stable in the three estimations. This means that performance in the previous period positively influences current performance. This result justifies the use of the GMM estimator in this part of our analysis. Firm network value has, as expected, a positive and significant impact on performance (models C.2 and C.3), which supports Hypothesis 4. The variable firms has a negative and significant influence on firm performance as a result of increasing rivalry and year dummies are also statistically significant. Population does not 
L. Fuentelsaz, E. Garrido and J.P. Maicas (2012).

A strategic approach to network value in network industries (JOM, Forthcoming)

seem to influence performance, except for model C.2 in which the influence is marginally negative.

Insert Table 6 about here

\section{DISCUSSION AND CONCLUSIONS}

This paper contributes to the study of markets with network effects from a strategic perspective by introducing network value as a key concept. We have empirically tested a conceptual model in which the firm's strategy may condition network effects and firm profitability through the three main elements that the literature has highlighted in network markets, i.e.: expectations, coordination and compatibility. Our research, by focusing on firm-initiated actions to leverage network effects, has led us to a greater understanding of firm-level strategy in network industries.

Our results reveal the importance of entry timing in markets with network effects. This result is highly consistent with previous findings (Gomez and Maicas, 2011; Usero and Fernández, 2009). Switching costs also appear as a key strategic tool that influences network value. High switching costs have been shown to dissuade the selection of a firm network by potential users with the subsequent negative effect on network value. Users distrust firms with high switching costs because they suspect that these firms will behave opportunistically (Mata et al., 1995), thus decreasing the effectiveness of network effects. Consequently, firms have to find a trade-off between creating high switching costs to retain their customers and being less aggressive so as to be perceived by potential customers as an appealing and trustworthy alternative. Contrary to what we expected, operating in various international markets is not a strategy that greatly influences users' expectations and, thus, its impact on 
network effects is not significant. The explanation we can provide for this unexpected finding in the industry is threefold. First, while it is true that a number of mobile service providers are competing globally, users are restricted in their choices to companies operating in their local markets. In mobile telecommunications, users take into account only the network of the country where they live whereas, in other information industries such as software, hardware and online auctions, users do not perceive national boundaries in their decisions. Second, the internationalization of mobile operators could have become a strategic necessity. This seems to be clear from an analysis of the recent evolution of the industry in which the international diversification of the main operators has been quite similar. Finally, the availability of roaming services in all European countries, the similarity of roaming coverage and charges within operators, and the lack of complete information for users about roaming charges within the operators of the same international group (Salsas and Koboldt, 2004) may limit the existence of international network effects. Summarizing, although international network effects could exist in the industry, current market conditions do not favor them.

Our research also analyzes how network value is an element that is positively related to firm performance. Our main premise is that users are willing to pay more for being part of a network with a larger installed base since the product does not provide any value by itself. The value comes from the communication ties that the network offers to users and this allows firms to increase the price of their product or service.

Through the analysis of the above relationships, this research makes a contribution by offering a more accurate measurement of network value. Traditionally, network value has been considered to be proportional to network size. Although this can be reasonable, in this paper we have added the intensity dimension to the traditional approach. We have adjusted previous measures by considering not only the firm's own network, but also its rivals' networks, that is, market competition is introduced into the assessment of network intensity 
L. Fuentelsaz, E. Garrido and J.P. Maicas (2012).

A strategic approach to network value in network industries (JOM, Forthcoming)

and, thus, network value. Although the main findings do not substantially change, the adjusted measure we use shows a lower network value, which is perfectly understandable as we consider the existence of other firms' networks that reduce users' utility since the probability of making off-net information exchanges with higher costs increases.

Our research has several managerial implications. It recommends paying special attention to entry timing strategies in network industries. Firms should try to attract users to their network as soon as possible to gain competitive advantage. Because of this, it is not surprising to observe that bargain-then-rip-off strategies are very common in the first stages of market evolution as an adequate mechanism to attract users that will be exploited at a later stage. Thus, entry timing and price strategy have to be considered simultaneously when network effects are important. However, firms in these markets should be aware of not overexploiting their customers when lock-in is a likely market outcome. The perception of high switching costs may lead users to suspect that firms will behave opportunistically, which could result in fewer incentives to enter into a relationship with the firm. This study also has implications for managers about the international diversification of mobile operators. Apparently, international presence has no impact on network value, which, in our view, does not mean that firms need not pay attention to their international strategy, but rather that it may have become a strategic necessity to survive in the industry.

We should not forget that our research setting refers to an industry in which the regulator plays a key role. For this reason, several policy implications can also be derived. Importantly, the effectiveness of FMA in the mobile communications industry depends on the winning of a license that is granted by national authorities and that is compulsory to compete for. Governments should be aware of the direct impact that their decisions have on competition in each local market. A reduced number of licenses or restrictive criteria to start an activity could reduce the number of competitors. This initial restriction could constitute an entry 
barrier in the future because a firm that cannot obtain a license at the first stage of competition will lose time in the market, which has been revealed as a valuable resource. Additionally, our results show the important effect of switching costs in reducing network value and consumers' welfare in network markets. Thus, the regulator should bear in mind that switching costs are a prevailing feature in the industry that can be harmful to customers' interests. Indeed, in the context of mobile communications, the regulator has already recognized the importance of this dimension, reducing switching barriers and developing several measures to make switching easier and less costly. Mobile number portability is, perhaps, the most noteworthy effort in this direction and it has had, according to the literature, the desired effects (Lee, Kim, Lee and Park, 2006).

To our knowledge, our paper is one of the first attempts to empirically integrate network size and network intensity as part of network value into firm strategy. However, several issues deserve further attention. First, we use an adjusted measure of network value, which does not confer the same importance to all users and takes into account the market position of each firm as a source of different network intensities. However, while it is true that we make an effort to incorporate several dimensions into our network value approach, the way in which we consider the tendency to make on-net communication only includes market shares and not price differences. Future research should try to improve the measure of network value with detailed data that reflects a more accurate dimension of the probability of making on-net over off-net connections by incorporating an explicit quantification of price discrimination. Although we take the existence of price discrimination as an issue, the inclusion of the degree of price discrimination as a source of network intensity and its evolution over time would improve the measure of network value. In the same vein, another possible extension would be to incorporate the existence of social network effects that reinforce network value. Users do not only select a firm because they believe it will be bigger than the others. Consumer 
L. Fuentelsaz, E. Garrido and J.P. Maicas (2012).

A strategic approach to network value in network industries (JOM, Forthcoming)

behavior is also influenced by the previous decisions of the people who are socially related to them.

Second, our paper has taken a theoretical approach to refer to the three antecedents of network effects and network value, i.e. user expectations and coordination, and compatibility. Although they have been useful to build the theoretical foundations of the impact of strategic choices on network value, a deeper understanding and quantification of these elements would constitute a promising avenue for further research.

Third, it has been shown that time in the market is an important determinant of network value. However, it would be interesting to analyze how this expectation of dominance of the first mover can be counteracted by late entrants and diminished over time. Although this paper has focused on the network-dependent value of a firm, further analysis should study how the improvement of network-independent value by late entrants can reduce the networkdependent advantages of early movers.

Finally, international presence has been shown not to have any significant impact on network value. Although some explanations have been put forward, a better understanding of how the internationalization process has influenced firm performance in these markets and become a strategic necessity is needed. The fact that various operators are competing simultaneously in the same markets would suggest the use of institutional or multimarket contact theories. Moreover, we have adopted a measure of the degree of internationalization that theoretically fits the mobile telecommunications industry. Our measure assumes the existence of international network effects, but does not quantify them. With the aim of overcoming this limitation, further studies should try to develop additional measures of international diversification to the specific context of network industries with international network effects. 
L. Fuentelsaz, E. Garrido and J.P. Maicas (2012).

A strategic approach to network value in network industries (JOM, Forthcoming)

\section{REFERENCES}

Amit, R. and Zott, C. (2001). "Value creation in e-business". Strategic Management Journal, 22(6/7): $493-520$.

Arellano, M. and Bover, O. (1995). "Another look at the instrumental variables estimation of errorcomponents models". Journal of Econometrics, 68(1): 29-51.

Arthur, W.B. (1989). "Competing Technologies, Increasing Returns, and Lock-In by Historical Events". The Economic Journal, 99(394): 116-131.

Arthur, W.B. (1990). "Positive Feedback in the Economy". Scientific American, 262(2): 92-99.

Arthur, W.B. (1996). "Increasing Returns and the New World of Business". Harvard Business Review, 74(4): 100-108.

Barkema, H.G. and Drogendijk, R. (2007). "Internationalizing in Small, Incremental or Larger Steps?” Journal of International Business Studies, 38(7): 1132-1148.

Bijwaard, G.E., Janssen, M.C.W. and Maasland, E. (2008). "Early mover advantages: An empirical analysis of European mobile phone markets”. Telecommunications Policy, 32(3-4): 246-261

Birke, D. and Swann, P. (2006). "Network Effects and the Choice of Mobile Operator". Journal of Evolutionary Economics, 16(1/2): 65-84.

Birke, D. and Swann, P. (2010). "Network effects, network structure and consumer interaction in mobile telecommunications in Europe and Asia”. Journal of Economic Behavior \& Organization, 76(2): 153-157

Blundell, R. and Bond, S. (1998). "Initial conditions and moment restrictions in dynamic panel data models". Journal of Econometrics, 87(1): 115-143.

Breusch, T.S. and Pagan, A. (1980). "The lagrange multiplier test and its applications to model specification in econometrics". The Review of Economic Studies, 47(1): 239-253.

Briscoe, B., Odlyzko, A. and Tilly, B. (2006). "Metcalfe's Law is wrong". IEEE Spectrum, 43(7): 3439.

Brock, D.M., Yaffe, T. and Dembovsky, M. (2006). "International Diversification and Performance: A Study of Global Law Firms". Journal of International Management, 12(4): 473-489.

Brown, C.L. and Lattin, J.M. (1994). "Investigating the Relationship between Time in Market and Pioneering Advantage". Management Science, 40(10): 1361-1369.

Brynjolfsson, E. and Kemerer, C. (1996). "Network Externalities in Microcomputer Software: An econometric analysis of the spreadsheet market". Management Science, 42(12): 1627-2647. 
L. Fuentelsaz, E. Garrido and J.P. Maicas (2012).

A strategic approach to network value in network industries (JOM, Forthcoming)

Burnham, T. A., Frels, J.K. and Mahajan, V. (2003). "Consumer Switching Costs: A Typology, Antecedents, and Consequences". Journal of the Academy of Marketing Science, 31(2): 109126.

Carlsson, F. and Löfgren, Å. (2006). "Airline Choice, Switching Costs and Frequent Flyer Programs". Applied Economics, 38(13): 1469-1475.

Carpenter, G.S. and Nakamoto, K. (1986). "Consumer Preference Formation and Pioneering Advantage". Journal of Marketing Research, 26(8): 285-298.

Chako, M. and Mitchell, W. (1998). "Growth Incentives to Invest in a Network Externality Environment". Corporate and Change, 7(4): 731-744

Chen, P-Y and Hitt, L.M. (2007). "Information Technology and Switching Costs". In T. Hendershott, ed., Handbook of Information Systems Economics.

Church, J.R., and Gandal, N. (2005). "Platform Competition in Telecommunications". Prepared for "The HandBook of Telecommunications Vol. 2" edited by M.Cave, S. Majumdar and I. Vogelsang.

Commission of the European Communities (2007). Commission Staff Working Document annex to the Communication from the Commission to the European Parliament, the Council, the European Economic and Social Committee and the Committee of the Regions. "European Electronic Communications Regulation and Markets 2006 (12 $2^{\text {th }}$ Report)". SEC (2007) 403

Commission of the European Communities (2009). Commission Staff Working Document accompanying the Commission Recommendation on the Regulatory Treatment of Fixed and Mobile Termination Rates in the EU. "Implications for Industry, Competition and Consumers". SEC (2009) 599

Corrocher, N. and Zirulia, L. (2009). "Me and you and everybody we know: An empirical analysis of local network effects in mobile communications". Telecommunications Policy, 33(1-2): 68-79

Cowan, R. (1990). "Nuclear Power Reactors: a Study in Technological Lock-in". The Journal of Economic History, 50(3): 541-567.

Curwen, P. \& Whalley, J. (2008). "The Internationalisation of Mobile Telecommunications. Strategic Challenges in a Global Market”. Edward Elgar, Northampton, United States

David, P. A. (1985). "Clio and the Economics of QWERTY". The American Economic Review, 75(2): 332-337.

De Palma, A. and Leruth, L. (1996). "Variable willingness to pay for network externalities with strategic standardization decisions”. European Journal of Political Economy, 12(2): 235-251.

Doganoglu, T. and Gryzbowski, L. (2007). "Estimating Network Effects in the Mobile Telephony in Germany". Information Economics and Policy, 19(1): 65-79. 
L. Fuentelsaz, E. Garrido and J.P. Maicas (2012).

A strategic approach to network value in network industries (JOM, Forthcoming)

Dranove, D. and Gandal, N. (2003). "The DVD-vs.-DIVX Standard War: Empirical evidence of network effects and preannouncement effects". Journal of Economics and Management Strategy, 12(3): 363-386.

Economides, N., and Himmelberg, C. (1995). "Critical mass and network evolution in telecommunications”. In G. Brock (ed.), “Toward a Competitive Telecommunication Industry”: $47-63$

Eisenmann, T.R. (2006). “Internet Companies' Growth Strategies: Determinants of Investment Intensity and Long-Term Performance”. Strategic Management Journal, 27(12): 1183-1204.

Farrell, J. and Saloner, G. (1986). "Installed Base and Compatibility: Innovation, Product Preannouncements, and Predation”. American Economic Review, 76(5): 940-955.

Farrell, J. and Klemperer, P. (2007). "Coordination and Lock-in: Competition with switching costs and network effects", in M.Amstrong and R. Porter (eds.) "Handbook of Industrial Organization, Vol.3", Elsevier.

Financial Times (2011). "Financial Times Global 500 Index".

Frels, J.K., Shervani, T. and Srivastava, R. (2003). "The Integrated Networks Model: Explaining Resource Allocations in Network Markets”. Journal of Marketing, 67(1): 29-45.

Fuentelsaz, L., Maicas, J.P. and Polo, Y. (2008). "The evolution of mobile communications in Europe: the transition from the second to the third generation". Telecommunications Policy, 32(6): 436-449.

Gandal, N. (1994). "The development of cable television in Israel". Telecommunications Policy, 18(4): $342-347$

Gandal, N. (2002). "Compatibility, Standardization, and Network Effects: Some Policy Implications". Oxford Review of Economic Policy, 18(1): 80-91.

Gandal, N., Kende, M. and Rob, R. (2002). "The dynamics of technological adoption in hardware/software systems: The case of compact disc players". The Rand Journal of Economics, 31(1): 43-61

García-Mariñoso, B. (2001). “Technological Incompatibility, Endogenous Switching Costs and LockIn”. The Journal of Industrial Economics, 49(3): 281-298.

Garud, R. and Kumaraswamy, A. (1993). "Changing competitive dynamics in network industries: An exploration of Sun Microsystems' open systems strategy". Strategic Management Journal, 14(5): 351-369.

Gerpott, T.J. \& Jakopin, N.M. (2005). "The degree of internationalization and the financial performance of European mobile network operators”. Telecommunications Policy, 29 (8): 635661 
L. Fuentelsaz, E. Garrido and J.P. Maicas (2012).

A strategic approach to network value in network industries (JOM, Forthcoming)

Ghoshal, S. (1987). “Global Strategy: An Organizing Framework”. Strategic Management Journal, 8(5): 425-440.

Gómez, J. and Maicas, J.P. (2011). "Do Switching Costs Mediate the Relationship between Entry Timing and Performance?”. Strategic Management Journal, 32(12): 1251-1269

Goolsbee, A. and Klenow, P.J. (2002). "Evidence on learning and network externalities in the diffusion of home computers". Journal of Law and Economics, 45(2): 317-333

Graack, C. (1996). "Telecom operators in the European Union: Internationalization strategies and network alliances", Telecommunications Policy 20(5): 341-355

Grajek, M. (2010). "Estimating Network Effects and Compatibility: Evidence from the Polish mobile market". Information Economics and Policy, 22(2): 130-143.

Grant, R.M. (2005). “Contemporary strategy analysis”. $5^{\text {th }}$ Edition. Blackwell Publishing.

Greene, W.H. (1993). “Econometric Analysis”, $2^{\text {nd }}$ Edition. MacMillan, New York.

Gruber, H. (2005). "The Economics of Mobile Telecommunications". Cambridge University Press, Cambridge, United Kingdom

Gruber, H. and Verboven, F. (2001). "The Diffusion of Mobile Telecommunications Services in the European Union”. European Economic Review, 45(3): 577-588.

Hartman, R.S. and Teece, D.J. (1990). "Product Emulation Strategies in The Presence of Reputation Effects and Network Externalities: Some Evidence from The Minicomputer Industry". Economics of Innovation and New Technology, 1(1/2): 157-182

Hausman (1978). “Specification Test in Econometrics”. Econometrica, 46(6): 1251-1272.

Hill, C.W.L. (1992). "Establishing a Standard: Competitive Strategy and Technological Standards in Winner-Take-All Industries”. Academy of Management Executive, 11(2): 7-25.

Hitt, M., Hoskisson, R.E. and Kim, H. (1997). "International Diversification: Effects on Innovation and Firm Performance in Product-Diversified Firms". Academy of Management Journal, 40(4): 767-798

Kalyanaram, G. and Urban, G.L. (1992). "Dynamic Effects of the Order of Entry on Market Share, Trial Penetration, and Repeat Purchases of Frequently Purchased Consumer Goods". Marketing Science, 11(3): 235-250.

Karakaya, F. and Stahl, M.J. (1989). "Barriers to Entry and Market Decisions in Consumer and Industrial Goods Markets". Journal of Marketing, 53(2): 80-91.

Katz, M. and Shapiro, C. (1985). "Network Externalities, Competition, and Compatibility". The American Economic Review, 75(3): 424-440.

Katz, M. and Shapiro, C. (1994). "Systems Competition and Network Effects". Journal of Economic Perspectives, 8(2): 93-115. 
L. Fuentelsaz, E. Garrido and J.P. Maicas (2012).

A strategic approach to network value in network industries (JOM, Forthcoming)

Kerin, R., Varadarajan,P.R. and Peterson, R.A. (1992). "First-Mover Advantage: A Synthesis, Conceptual Framework, and Research Propositions". Journal of Marketing, 56(4): 33-52.

Kim, H. and Kwon, N. (2003). "The Advantage of Network Size in Acquiring New Subscribers: A conditional logit analysis of the Korean telephony market". Information Economics and Policy, 15(1): 17-33.

Klemperer, P. (1995). "Competition When Consumers Have Switching Costs: An Overview With Applications to Industrial Organization, Macroeconomics and International Trade". Review of Economic Studies, 62(213): 515-539.

Krafft, J. and Salies, E. (2008). "The diffusion of ADSL and costs of switching Internet providers in the broadband industry: Evidence from the French case". Research Policy, 37(4): 706-719.

Laffont, J.J., Rey. P. and Tirole, J. (1998). "Network Competition: II. Price Discrimination". Rand Journal of Economics, 29(1): 38-56.

Lambkin, M. (1988). "Order of Entry and Performance in New Markets". Strategic Management Journal, 9(5): 127-140.

Lane, V. and Jacobson, R. (1995). "Stock Market Reactions to Brand Extension Announcement: The Effects of Brand Attitude and Familiarity". Journal of Marketing, 59(1): 63-77.

Lee, D. and Mendelson, H. (2007). "Adoption of Information Technology Under Network Effects". Information Systems Research, 18(4): 395-413.

Lee, J., Kim, Y., Lee, J.D. and Park, Y. (2006). "Estimating the Extent of Potential Competition in the Korean Mobile Telecommunications Market: Switching Costs and Number Portability". International Journal of Industrial Organization, 24(1): 107-124.

Lieberman, M.B. and Montgomery, D.B. (1988). "First-mover Advantages". Strategic Management Journal, 9(S1): 41-58.

Liebenstein, H. (1950). "Bandwagon, Snob and Veblen Effects in the Theory of Consumers' Demand". The Quarterly Journal of Economics, 64(2): 183-207.

Maicas, J.P., Polo, Y. and Sese, J. (2009). "The role of (personal) network effects and switching costs in determining mobile users' choice”. Journal of Information Technology, 24(2): 160-171.

Majumdar, S.K. and Venkataraman, S. (1998). "Network effects and the adoption of new technology: Evidence from the U.S. telecommunications industry". Strategic Management Journal, 19(11): 1045-1062.

Mata, F., Fuerst, W. and Barney, J.B. (1995). "Information Technology and Sustained Firm-Level Value: a Resource-Based Analysis". MIS Quarterly, 19(4): 487-505.

McCloughan, P. and Lyons, S. (2006) “Accounting for ARPU: New evidence from international panel data". Telecommunications Policy, 30(10-11): 521-532. 
L. Fuentelsaz, E. Garrido and J.P. Maicas (2012).

A strategic approach to network value in network industries (JOM, Forthcoming)

McIntyre, D.P. (2011). "Where there's a way, is there a will? Installed base and product quality in a network industry". Journal of High Technology Management Research, 22(1): 59-66

McIntyre, D.P. and Subramaniam, M. (2009). "Strategy in Network Industries: A Review and Research Agenda". Journal of Management, 35(6): 1494-1517.

Merrill Lynch (2010). “Global Wireless Matrix 2009”.

Ofcom (2007). “The Communications Market”, United Kingdom.

Ofcom (2009). Review of mobile tariffs in the UK and US, Annex 9 in "Wholesale Mobile Voice Call Termination".

Ofcom (2011). "Three response to mobile call termination supplemental consultation: the relationship between mobile termination rates, market share and competition". United Kingdom.

Park, S. (2004). "Quantitative Analysis of Network Externalities in Competing Technologies: The VCR Case". The Review of Economics and Statistics, 86(4): 937-945.

Reed, D.P. (1999) “That sneaky exponential: Beyond Metcalfe's Law to the Power of Community Building”. Context, Spring available at: http://www.contextmag.com/archives/199903/digitalstrategyreedslaw.asp.

Rohlfs, J.H. (1974). "Theory of Interdependent Demand for a Communications Service". The Bell Journal of Economics and Management Science, 5(1): 16-37.

Rohlfs, J.H. (2001). "Bandwagon Effects in High Technology Industries". MIT Publishing.

Roodman (2006). "How to Do xtabond2: An introduction to "Difference" and "System" GMM in Stata”. Working Paper 103, Center for Global Development, Washington.

Ross, P.E. (2003). "5 Commandments: Technology Laws and Rules of Thumb". IEEE Spectrum, 40(12): 30-35.

Salsas, R. and Koboldt, C. (2004). "Roaming free? Roaming network selection and inter-operator tariffs". Information Economics and Policy, 16(4): 497-517

Sarkar, M.B., Cavusgil, S.T. and Aulakh, P.S. (1999). "International Expansion of Telecommunications Carriers: The Influence of Market Structure, Network Characteristics, and Entry Imperfections". Journal of International Business Studies, 30(2): 361-382.

Schilling, M.A. (2002). "Technology Success and Failure in Winner-Take-All Markets: the Impact of Learning Orientation, Timing, and Network Externalities". Academy of Management Journal, 45(2): 387-398.

Shankar, V. and Bayus, B.L. (2003). "Network Effects and Competition: an Empirical Analysis of the Home Video Game Industry”. Strategic Management Journal, 24(4): 375-384.

Schmalensee, R. (1982). "Product Differentiation Advantages of Pioneering Brands". The American Economic Review, 72(3): 349-365. 
L. Fuentelsaz, E. Garrido and J.P. Maicas (2012).

A strategic approach to network value in network industries (JOM, Forthcoming)

Shapiro, C. and Varian, H.R. (1998). Information Rules: a Strategic Guide to the Network Economy. Harvard Business School, Boston.

Shy, O. (2001). "The Economics of Network Industries". Cambridge University Press. Cambridge, United Kingdom.

Shy, O. (2002). “A Quick-and-Easy Method for Estimating Switching Cost”. International Journal of Industrial Organization, 20(1): 71-81.

Shy, O. (2011). “A Short Survey of Network Economics”. Review of Industrial Organization, 38(2): 119-149.

Srinivasan, R., Lilien, G.L. and Rangaswamy, A. (2004). "First in, First out? The Effects of Network Externalities on Pioneer Survival”. Journal of Marketing, 68(1): 41-58.

Stabell C.B. and Fjeldstad Ø.D. (1998). "Configuring value for competitive advantage: on chains, shops, and networks". Strategic Management Journal, 19(5): 413-437.

Stango, V. (2002). "Pricing with Consumer Switching Costs: Evidence from the Credit Card Market". Journal of Industrial Economics, 50(4): 475-492.

Strike, V., Gao, J. and Bansal, P. (2006). "Being Good while Being Bad: Social Responsibility and the International Diversification of US Firms". Journal of International Business Studies, 37(6): $850-862$.

Suarez, F. (2005). "Network Effects Revisited: The role of ties in technology selection". Academy of Management Journal, 48(4): 710-720.

Swann, P. (2002). "The Functional Form of Network Effects". Information Economics and Policy, 14(3): 417-429.

Tanriverdi, H. and Lee, C.H. (2008). "Within-industry Diversification and Firm Performance in the Presence of Network Externalities: Evidence from the Software Industry". Academy of Management Journal, 51(2): 381-397.

Usero, B. and Fernández, Z. (2009). "First come, first served: How market and non-market actions influence pioneer market share". Journal of Business Research, 62(11): 1139-1145.

Viard, B. (2007). "Do Switching Costs Make Markets More or Less Competitive? The Case of 800Number Portability". Rand Journal of Economics, 38(1): 146-164.

World Bank Group (2010). “World Development Indicators Online”. 
L. Fuentelsaz, E. Garrido and J.P. Maicas (2012).

A strategic approach to network value in network industries (JOM, Forthcoming)

\section{FOOTNOTES}

${ }^{1}$ The literature has traditionally distinguished between direct and indirect network effects. The first refer to when "adoption by different users is complementary, so that each user's adoption payoff, and his incentive to adopt, increases as more others adopt". The second arise "through improved opportunities to trade with the other side of a market" (Farrell and Klemperer, 2007: 1974). This paper focuses its attention on direct network effects, although most of the arguments offered would also stand for indirect network effects.

${ }^{2}$ Our research focuses on the network value that is directly dependent on the existence of other users consuming the product, that is, the value that comes from the existence of network effects. McIntyre and Subramaniam (2009) also identify a part of network value that can be network-independent. This network-independent value captures quality characteristics of the product that "are under the full control of the producer" (Bental and Spiegel, 1995:197), such as, in our industry, network coverage or network reliability. Accordingly to McIntyre (2011), companies with higher network value also tend to offer, from the organizational learning perspective, greater network-independent value since they have accumulated more experience and capabilities in the industry.

${ }^{3}$ As we will explain in Section 3, the importance of the stage of the product life cycle has been considered in our measure of the network value by differentiating between early and late adopters.

${ }^{4}$ The value of rival networks has also been taken into account when calculating the measure of network value that we propose in the article. For more details, see Section 3.

${ }^{5}$ It must be noted that this study will focus on the scope of the firm's network and not on the total size of the market. This is because, in some cases, the products or services of different firms do not necessarily facilitate interaction between users. Apart from technological incompatibility, we can also find artificial or economic incompatibility, which is based on price discrimination between on-net and off-net communication exchanges (Laffont, Rey and Tirole, 1998). Price discrimination generates tariff-mediated network effects, which appear at firm-level instead of industry-level (Grajek, 2010). This is precisely the situation of our research setting. A further discussion about economic incompatibility and price discrimination in the mobile communications industry is contained in the description of the research setting (Section 3).

${ }^{6}$ For further information, see Commission of the European Communities $(2007,2009)$ and Ofcom (2007). 
L. Fuentelsaz, E. Garrido and J.P. Maicas (2012).

A strategic approach to network value in network industries (JOM, Forthcoming)

${ }^{7}$ The European countries considered in our research are Austria, Belgium, the Czech Republic, Denmark, Finland, France, Germany, Greece, Hungary, Ireland, Israel, Italy, the Netherlands, Norway, Poland, Portugal, Spain, Sweden, Switzerland and the United Kingdom.

${ }^{8}$ Licenses granted by governments give the number of firms competing in a country. These licenses allow operators to use the radio spectrum inside the country. This means that, although international groups operate in several countries, our unit of analysis is the firm-market pair (e.g., Vodafone Spain, Orange France and $\mathrm{O}_{2}$ Germany).

${ }^{9}$ As mentioned in footnote 5, the literature has referred to this phenomenon as tariff or price-mediated network effects (Laffont, Rey and Tirole, 1998; Birke and Swann, 2006), and these lead to artificial or economic incompatibility among firm networks.

${ }^{10}$ Thanks to an anonymous reviewer's suggestion, we built an alternative measure of internationalization by considering, for every operator, the percentage of users abroad over the total users. Both measures are highly correlated $(\mathrm{r}=0.754)$ and results do not substantially differ. 
L. Fuentelsaz, E. Garrido and J.P. Maicas (2012).

A strategic approach to network value in network industries (JOM, Forthcoming)

TABLE 1.

EXAMPLE

Market A

Market B

Firm 1

$60 \%(1,200$ subscribers $)$

$80 \%(1,200$ subscribers $)$

Firm 2

$40 \%$ (800 subscribers)

$20 \%$ (300 subscribers)

Table 2.

Likelihood Matrix of Calls ACross Networks

\begin{tabular}{|c|c|c|c|c|c|c|}
\hline & & & \multicolumn{4}{|c|}{ To Network } \\
\hline & & & 1 & 2 & 3 & 4 \\
\hline \multirow{4}{*}{ 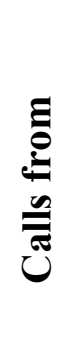 } & \multirow{4}{*}{ 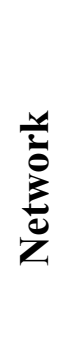 } & 1 & $m_{1} m_{1}$ & $m_{1} m_{2}$ & $m_{1} m_{3}$ & $m_{1} m_{4}$ \\
\hline & & 2 & $m_{2} m_{1}$ & $m_{2} m_{2}$ & $m_{2} m_{3}$ & $m_{2} m_{4}$ \\
\hline & & 3 & $m_{3} m_{1}$ & $m_{3} m_{2}$ & $m_{3} m_{3}$ & $m_{3} m_{4}$ \\
\hline & & 4 & $m_{4} m_{1}$ & $m_{4} m_{2}$ & $m_{4} m_{3}$ & $m_{4} m_{4}$ \\
\hline
\end{tabular}

Source: Birke and Swann (2006). 
L. Fuentelsaz, E. Garrido and J.P. Maicas (2012).

A strategic approach to network value in network industries (JOM, Forthcoming)

Table 3.

Descriptive Statistics Model $1(\mathrm{~N}=\mathbf{2 , 0 3 2})$

\begin{tabular}{|c|c|c|c|c|c|c|c|c|c|c|c|}
\hline Variable & Mean & Std. Dev. & Min & Max & 1 & 2 & 3 & 4 & 5 & 6 & 7 \\
\hline 1. NETWORK VALUE & 15.28 & 24.09 & -0.37 & 140.08 & - & & & & & & \\
\hline 2. NETWORK VALUE' & 9.25 & 17.14 & -0.13 & 105.38 & $0.92^{*}$ & - & & & & & \\
\hline 3. TIME & 107.48 & 44.36 & 3.00 & 258.00 & $0.37^{*}$ & $0.33^{*}$ & - & & & & \\
\hline 4. INTERNATIONALIZATION & 7.95 & 7.04 & 1.00 & 28.00 & $0.28^{*}$ & $0.21^{*}$ & $0.31^{*}$ & - & & & \\
\hline 5. SWITCHING COSTS & 17.22 & 11.19 & -18.28 & 56.51 & $0.07^{*}$ & $0.15^{*}$ & $0.24^{*}$ & $0.13^{*}$ & - & & \\
\hline 6. FIRMS & 3.27 & 0.65 & 2.00 & 5.00 & $0.14^{*}$ & 0.03 & $-0.10^{*}$ & $0.15^{*}$ & 0.02 & - & \\
\hline 7. POPULATION & 27.12 & 25.64 & 3.87 & 82.541 & $0.76^{*}$ & $0.56^{*}$ & $0.08^{*}$ & $0.13^{*}$ & -0.02 & $0.31^{*}$ & - \\
\hline
\end{tabular}

$* p<0.01$

Table 4.

Descriptive Statistics Model 2 (N=1,991)

\begin{tabular}{|c|c|c|c|c|c|c|c|c|c|c|}
\hline Variable & Mean & Std. Dev. & Min & $\operatorname{Max}$ & 1 & 2 & 3 & 4 & $\overline{5}$ & $\overline{6}$ \\
\hline 1. PERFORMANCE $t$ & 0.29 & 0.24 & -3.57 & .58 & - & & & & & \\
\hline 2. PERFORMANCE ${ }_{t-1}$ & 0.28 & 0.38 & -9.17 & 0.58 & $0.90^{*}$ & - & & & & \\
\hline 3. NETWORK VALUE & 15.59 & 24.29 & -0.37 & 140.08 & $0.16^{*}$ & $0.17^{*}$ & - & & & \\
\hline 4. NETWORK VALUE' & 9.54 & 17.49 & -0.07 & 105.38 & $0.18^{*}$ & $0.18^{*}$ & $0.91^{*}$ & - & & \\
\hline 5. FIRMS & 3.28 & 0.66 & 2.00 & 5.00 & $-0.14^{*}$ & $-0.15^{*}$ & $0.14^{*}$ & 0.03 & - & \\
\hline 6. POPULATION & 26.48 & 25.57 & 3.87 & 82.54 & -0.01 & 0.01 & $0.73^{*}$ & $0.57^{*}$ & $0.31^{*}$ & - \\
\hline
\end{tabular}

$* p<0.01$ 
L. Fuentelsaz, E. Garrido and J.P. Maicas (2012).

A strategic approach to network value in network industries (JOM, Forthcoming)

TABLE 5.

Determinants of Network VAlue (FE)

\begin{tabular}{|c|c|c|c|c|c|c|c|c|}
\hline & \multicolumn{4}{|c|}{ NETWORK VALUE } & \multicolumn{4}{|c|}{ NETWORK VALUE' } \\
\hline & (A.1) & (A.2) & (A.3) & (A.4) & (B.1) & (B.2) & (B.3) & (B.4) \\
\hline TIME & & $\begin{array}{c}0.242^{* * *} \\
(5.70)\end{array}$ & $\begin{array}{c}0.229^{* * *} \\
(5.46)\end{array}$ & $\begin{array}{c}0.224^{* * *} \\
(6.06)\end{array}$ & & $\begin{array}{c}0.117^{* * *} \\
(4.81)\end{array}$ & $\begin{array}{c}0.113^{* * *} \\
(4.74)\end{array}$ & $\begin{array}{c}0.110^{* * *} \\
(5.31)\end{array}$ \\
\hline INTERNATIONALIZATION & & & $\begin{array}{l}0.230 \\
(1.02)\end{array}$ & $\begin{array}{l}0.168 \\
(0.79)\end{array}$ & & & $\begin{array}{l}0.076 \\
(0.59)\end{array}$ & $\begin{array}{l}0.035 \\
(0.30)\end{array}$ \\
\hline SWITCHING COSTS & & & & $\begin{array}{l}-0.539^{* *} \\
(-2.60)\end{array}$ & & & & $\begin{array}{c}-0.348^{* * *} \\
(-2.90)\end{array}$ \\
\hline FIRMS & $\begin{array}{l}1.899 \\
(1.12)\end{array}$ & $\begin{array}{l}1.971 \\
(1.17)\end{array}$ & $\begin{array}{l}1.781 \\
(1.09)\end{array}$ & $\begin{array}{l}4.636^{* *} \\
(2.37)\end{array}$ & $\begin{array}{l}0.006 \\
(0.01)\end{array}$ & $\begin{array}{l}0.042 \\
(0.04)\end{array}$ & $\begin{array}{l}-0.020 \\
(-0.02)\end{array}$ & $\begin{array}{l}1.823 \\
(1.44)\end{array}$ \\
\hline POPULATION & $\begin{array}{c}6.225^{* * *} \\
(3.48)\end{array}$ & $\begin{array}{c}6.210^{* * *} \\
(3.47)\end{array}$ & $\begin{array}{c}5.991^{* * *} \\
(3.16)\end{array}$ & $\begin{array}{c}6.434^{* * *} \\
(4.06)\end{array}$ & $\begin{array}{l}2.855^{* *} \\
(2.50)\end{array}$ & $\begin{array}{c}2.847^{* *} \\
(2.49)\end{array}$ & $\begin{array}{l}2.776^{* *} \\
(2.35)\end{array}$ & $\begin{array}{c}3.062^{* * *} \\
(3.07)\end{array}$ \\
\hline YEAR Dummies & $\mathrm{YES}^{* * *}$ & $\mathrm{YES}^{* * *}$ & $\mathrm{YES}^{* * *}$ & $\mathrm{YES}^{* * *}$ & YES $^{*}$ & $\mathrm{YES}^{* *}$ & $\mathrm{YES}^{* *}$ & YES $^{* *}$ \\
\hline Number of observations & 2,032 & 2,032 & 2,032 & 2,032 & 2,032 & 2,032 & 2,032 & 2,032 \\
\hline$R 2$ & 0.524 & 0.530 & 0.534 & 0.600 & 0.370 & 0.373 & 0.375 & 0.463 \\
\hline F-Test vs. 1 & & $32.55^{* * *}$ & $16.70^{* * *}$ & $15.37^{* * *}$ & & $23.14^{* * *}$ & $11.80^{* * *}$ & $11.51^{* * *}$ \\
\hline F-Test vs. 2 & & & 1.03 & $3.68^{* *}$ & & & 0.34 & $4.21^{* *}$ \\
\hline F-Test vs. 3 & & & & $6.74^{* *}$ & & & & $8.41^{* * *}$ \\
\hline
\end{tabular}

$t$ statistics in parentheses

* $p<0.10$

** $\quad p<0.05$

*** $p<0.01$ 
L. Fuentelsaz, E. Garrido and J.P. Maicas (2012).

A strategic approach to network value in network industries (JOM, Forthcoming)

TABLe 6.

Performance ANd Network Value (System GMM)

\begin{tabular}{|c|c|c|c|}
\hline & $\begin{array}{c}\text { (C.1) } \\
\text { PERFORMANCE }_{\mathrm{t}}\end{array}$ & $\begin{array}{c}\text { (C.2) } \\
\text { PERFORMANCE }_{t}\end{array}$ & $\begin{array}{c}\text { (C.3) } \\
\text { PERFORMANCE }_{\mathrm{t}}\end{array}$ \\
\hline NETWORK VALUE & & $\begin{array}{l}0.002^{* * *} \\
(3.99)\end{array}$ & \\
\hline NETWORK VALUE' & & & $\begin{array}{l}0.003^{* * *} \\
(2.97)\end{array}$ \\
\hline PERFORMANCE $_{t-1}$ & $\begin{array}{c}0.467^{* * *} \\
(20.56)\end{array}$ & $\begin{array}{c}0.467^{* * *} \\
(19.60)\end{array}$ & $\begin{array}{c}0.464^{* * *} \\
(19.75)\end{array}$ \\
\hline FIRMS & $\begin{array}{c}-0.047^{* * *} \\
(-3.04)\end{array}$ & $\begin{array}{c}-0.041^{* * *} \\
(-2.92)\end{array}$ & $\begin{array}{l}-0.036^{* *} \\
(-2.46)\end{array}$ \\
\hline POPULATION & $\begin{array}{l}0.001 \\
(1.24)\end{array}$ & $\begin{array}{l}-0.001^{*} \\
(-1.75)\end{array}$ & $\begin{array}{l}-0.001 \\
(-1.21)\end{array}$ \\
\hline YEAR Dummies & YES $^{* * *}$ & $\mathrm{YES}^{* * *}$ & $\mathrm{YES}^{* * *}$ \\
\hline Constant & $\begin{array}{l}0.316^{* * *} \\
(7.26)\end{array}$ & $\begin{array}{l}0.286^{* * *} \\
(7.48)\end{array}$ & $\begin{array}{c}0.274^{* * *} \\
(6.94)\end{array}$ \\
\hline $\begin{array}{l}\text { Number of observations } \\
\text { m1 } \\
\text { m2 } \\
\text { Hansen Test } \\
\text { F-Test vs. } 1 \\
\end{array}$ & $\begin{array}{c}1991 \\
-2.92^{* * *} \\
-0.04 \\
37.64\end{array}$ & $\begin{array}{c}1991 \\
-2.95^{* * *} \\
-0.04 \\
53.76 \\
15.88^{* * *} \\
\end{array}$ & $\begin{array}{c}1991 \\
-2.94^{* * *} \\
-0.04 \\
48.16 \\
8.85^{* * *} \\
\end{array}$ \\
\hline $\begin{array}{l}t \text { statistics in parentheses } \\
{ }^{*} p<0.10 \\
{ }^{* *} p<0.05 \\
{ }^{* * *} p<0.01\end{array}$ & & & \\
\hline
\end{tabular}

